\title{
Differences in Tip-of-the-Tongue Phenomenon and Resolving Patterns according to Vocabulary Characteristics between Young and Elderly Adults
}

\author{
Ye Ni Lee ${ }^{a}$, So Young Choi ${ }^{\text {b }}$ \\ aDepartment of Special Education, Graduate School, Dankook University, Yongin, Korea \\ ${ }^{b}$ Graduate School of Special Education, Dankook University, Yongin, Korea
}

Correspondence: So Young Choi, $\mathrm{PhD}$ Graduate School of Special Education, Dankook University, 152 Jukjeon-ro, Suji-gu, Yongin 16890, Korea

Tel: $+82-31-8005-3813$

Fax: +82-31-8021-7144

E-mail: syc529@dankook.ac.kr

Received: January 5, 2016

Revised: February 8, 2016

Accepted: February 26, 2016

This work was supported by the Lee Seung Hwan's Scholarship from the Korean Academy of SpeechLanguage Pathology and Audiology in 2015.

\begin{abstract}
Objectives: This study examined Tip-of-the-Tongue (TOT) phenomenon incidence and resolving pattern differences in accordance with normal aging focusing on breakdown of phonological information production in naming processing. Methods: TOT phenomenon was induced through naming tasks according to word category and frequency, targeting 20 young people (age 20 to 29) and 20 elderly people (age 70 and over). Results: TOT phenomenon incidence occurred more often in the elderly than in the youth. In both groups, it occurred more often in proper nouns than in common nouns, and it occurred more often in low frequency words than in high frequency words among common nouns, where the elderly showed a greater difference. Although the TOT phenomenon occurred according to word category and frequency of common nouns in both the youth and elderly more retrieval cues were needed to resolve the TOT phenomenon in the elderly group. Conclusion: This study empirically demonstrates that aging affects the process of phonological information production and the incidence and resolution aspects of TOT phenomenon, and it provides basic data on vocabulary characteristics which may affect the process.
\end{abstract}

Keywords:Tip-of-the-Tongue phenomenon, Aging, Naming, Word category, Word frequency
노화가 진행되면서 감퇴되는 언어 산출 능력과 관련하여, 연령이 증가함에 따라 단어에 대한 기본적인 지식은 유지되지만 단어 정 보 인출에 어려움을 겪기 때문에 이름대기의 어려움이 두드러지게 나타난다(Le Dorze \& Durocher, 1992). 이름대기는 특정 사람, 사 물, 장소 및 행동에 대한 이름을 산출하는 언어 능력을 필요로 하 는데(Nicholas, Barth, Obler, Au, \& Albert, 1997), 연령은 이러한 이름대기 능력에 영향을 미치는 대표적인 변인이며 그 외에도 단어 의 범주나 빈도 등이 영향을 미치는 것으로 알려져 있다(Hodgson \& Ellis, 1998). 이름대기 능력의 감소와 관련하여 다수의 노인들이 보고하는 자발적 불만 중 하나는 고유명사인 사람과 장소 및 일반 명사인 사물에 해당되는 이름을 기억하는 것에 어려움이 있다는 것이다(Cohen \& Faulkner, 1986). 이러한 어려움은 노인이 이름을 알고 있음에도 생각나지 않기 때문에 나타나며, 결과적으로 어휘 산출 과정에서 노인은 청년에 비해 속도 및 정확성이 현저히 떨어지
게 된다(Park, 2015). 정상 성인을 대상으로 대면이름대기 과제 수 행을 비교한 다수의 연구 결과에서 연령에 따른 이름대기 수행의 차이가 보고되었고(Connor, Spiro, Obler, \& Albert, 2004; Farmer, 1990; Goulet, Ska \& Kahn, 1994; Nicholas et al., 1997), 공통적으로 노인집단이 청년집단에 비해 이름대기 능력의 감소와 더불어 더 많 은 이름대기 오류를 보이는 것으로 나타났다. 그 원인 중 하나는 청 년에 비해 노인의 경우 음운 정보 전달을 위한 연결이 약화됨에 따 라, 더 적은 음운 정보를 사용하기 때문이다(Burke, Mackay, Worthley \& Wade, 1991; Cohen \& Faulkner, 1986; Maylor 1990). 이와 같은 특성이 반영된 결과로, 청년보다 노인들은 더 빈번하게 설단 현상을 경험한다(Brown \& Nix, 1996).

설단 현상(Tip-of-the-Tongue phenomenon, TOT phenomenon)이란 완전한 단어를 떠올릴 수는 없으나, 비슷한 형태와 의미 를 지닌 단어는 기억해 낼 수 있는 상태를 말한다(Brown \& Mc- 
Neill, 1966). 설단 현상은 단어를 알고 있다는 친숙함에 의해 의미 정보와 어휘 표현이 활성화될 때 경험할 수 있지만, 동시에 음운 정 보의 활성화가 불완전하거나(Burke \& Shafto, 2004), 음운 형태를 일시적으로 처리할 수 없기 때문에 발생하게 된다(Evrard, 2002). 선행 연구에서 설단 현상의 발생을 설명하고자 한 가설로 차단 가 설(blocking hypothesis)과 불완전 활성화 가설(incomplete activation hypothesis), 그리고 전달 손실 가설(transmission deficit hypothesis)을 들 수 있다. 먼저 차단 가설은 목표 단어 인출을 위한 검색 시 밀접하게 관련된 단어(blocker/interloper)도 함께 떠오르 게 되고, 이때 관련 단어가 정확한 목표 단어의 인출을 차단(blocking)하여 설단 현상이 발생한다고 보았다(Jones, 1989; Schwartz, 1999). 불완전 활성화 가설은 목표 단어의 의미와 형태가 완전히 연 결되지 않거나, 제한된 연결로 인해 목표 단어 회상이 실패하였을 때 설단 현상이 발생한다고 하였다(Ecke \& Garrett, 1998). 마지막 으로 전달 손실 가설에서는 어휘 처리가 부분적으로 활성화되었을 때 의미 정보에 대한 접근은 가능하지만, 일부 음운 정보의 전달이 불충분하여 비활성화상태가 유지되기 때문에 설단 현상이 발생한 다고 보았다(Burke et al., 1991). 불완전 활성화 가설과 전달 손실 가설의 제안들에서 일부 공통되는 부분은 설단 현상을 해결하기 위해서 단절 혹은 불충분한 정보 전달을 보충하기 위한 단서가 필 요하다는 점이다(Dahlgren, 1998; Schwartz, 1999).

이러한 설단 현상의 발생은 일반적으로 노화가 진행됨에 따라 증 가하는 것으로 여겨지나(Brown \& Nix, 1996; Heine, Ober, \& Shenaut, 1999; Rastle \& Burke, 1996), 연령에 따른 차이 외에도 사 람, 장소, 사물 이름, 동사 및 형용사와 같은 세부적인 단어 범주에 따라 정도는 달라질 수 있다(Park, Lee, \& Lee, 2013). Evrard (2002) 는 연령의 증가에 따라 일반명사(common noun)보다 고유명사 (proper noun) 인출에 어려움을 겪기 때문에, 일반적으로 설단 현 상이 일반명사에 비해 고유명사에서 더 빈번하게 나타난다고 언급 하였다. 특히 노인집단은 일반명사에 비해 고유명사에서 더 빈번하 게 설단 현상을 경험하며, 단어를 기억해내기 위해 더 많은 노력이 필요하다고 보고되었다. Ellis와 Young (1989)이 제시한 사물 이름 대기를 위한 인식 과정(object recognition process)에 따르면, 우선 초기 대상 인식(initial representation)을 통한 시각적 정보를 활용 하여 사물의 모양이나 크기를 파악한다. 이 과정에서 입력된 시각 적 정보들은 대상자의 기억 속에 저장되어 있는 사물 인식 단위체 (object recognition unit)의 활성화를 통해 사물로 인식되며, 이는 시각적 정보와 의미적 정보 사이의 접점 역할을 하게 된다. 이후 해 당 사물의 특성과 속성을 지칭하는 의미 정보가 저장된 의미적 체 계(semantic system) 과정에 도달한 뒤, 어휘적 체계(speech output lexicon system)와 음운 산출 체계(phonological output system)를 거쳐 적절한 사물의 이름을 말하게 된다.

반면 사람 이름과 관련된 고유명사 이름대기를 위한 Bruce와 Young (1986)의 얼굴 인식 과정(face recognition process)에 의하 면, 먼저 시각적 구조화(structural encoding)를 통해 얼굴의 시각 적 속성을 분석한 뒤 대상자에게 친숙한 얼굴은 얼굴 인식 장치 (face recognition units)에 저장된다. 친숙한 정도에 따라 얼굴 인식 장치는 활성화되며, 이후 사람 확인 마디(person identity node)에 정보를 전달한다. 이 단계에서는 확인-특정 의미 마디(identity-specific semantic codes)와 접근할 수 있으며, 이는 이름을 제외하고 그 외에 알려진 개인적 정보(예: 누구와 결혼을 했는지, 직업, 성격 특 성 등)를 알려주게 된다. 확인-특정 의미 마디에 해당 인물과 관련 한 정보 중 대해 유일하게 저장되지 않은 정보는 이름이며, 이는 별 도로 저장되어 확인-특정 의미 마디에 접근한 뒤 활성화된다. 이후 사람 이름 기본 정보(lemmas for person's names)와 음운 산출 체 계를 거쳐 적절한 사람의 이름을 말하게 된다(Valentine, Brennen \& Brédart, 1995), 즉, 앞서 언급된 단어 범주에 따른 설단 현상 발생 의 차이는 이름대기 수행에 요구되는 어휘 처리 과정과 관련된 이 론들에서 사람 이름과 관련한 고유명사 이름대기 처리과정이 일반 명사 처리 과정보다 더 복잡한 것으로 추정된 바에 의해 설명될 수 있을 것이다(Robson, Marshall, Pring, Montagu, \& Chiat, 2004).

Burke 등(1991)은 고유명사와 일반명사의 경우 동일한 음운 체 계를 공유하고 있으나, 연결 구조의 차이로 인해 단어 범주에 따라 설단 현상 발생의 차이가 나타날 수 있다고 보았다. 즉, 일반명사와 관련된 의미 정보를 나타내는 어휘 마디는 다수의 의미 마디와 직 접 연결되어 의미 점화를 통해 음운 마디와 연결되어 이름을 산출 하게 되는 반면, 고유명사의 경우 일반명사와 달리 의미 정보를 나 타내는 어휘 마디가 해당 어휘가 지칭하는 단 하나의 의미 마디와 유일하게 연결되어 있다. 따라서 의미 점화 전달의 부족으로 음운 마디에 적절한 정보가 수신되지 않으면 친숙한 사람이더라도 설단 현상을 경험하게 된다. 또한, 단어 빈도(word frequency) 역시 설단 현상의 발생에 영향을 미칠 수 있다(Burke et al., 1991; Burke \& Shafto, 2004). 일반명사 중 고빈도 단어보다 저빈도 단어에서 더 많 은 설단 현상이 발생함을 보고한 연구 결과들은 단어의 사용 빈도 가 이름대기 정확도에 영향을 미침을 보여주었고, 이는 마디 간 연 결의 효율성이 연령에 따라 감소하며 정보 활성화의 감소는 저빈도 단어에서 더 많이 나타나게 됨을 시사하는 것으로 여겨졌다(Burke \& Laver, 1990; Burke \& Shafto, 2004; Harley \& Bown, 1998; Hodgson \& Ellis, 1998).

이처럼 설단 현상의 발생에 미치는 변인들의 영향은 비교적 유사 
한 양상으로 측정되어온 반면, 설단 현상이 해결되는 과정에 대해 서는 연구들마다 다양한 접근이 시도되고 있다. 일반적으로 사람 들은 설단 현상이 발생했을 때 이를 해결하기 위하여 음운 사이의 연결을 강화시키는 음운 점화(phonological priming)를 시도한다 (Burke \& Shafto, 2008; James \& Burke, 2000). 이 같은 양상을 유도 하기 위해 통제된 실험 연구들은 음절 단서(Abrams, White, \& Eitel, 2003; Beeson, Holland, \& Murray, 1997; Brown \& Nix, 1996; Juncos-Rabadán, Facal, Lojo-Seoane, \& Pereiro, 2013)와 단어 재인 (Beeson et al., 1997; Brown \& Nix, 1996; Burke et al., 1991; Park et al., 2013)을 비롯하여, 의미적 접근의 활성화를 위한 의미 정보 (Beeson et al., 1997; Hanley \& Chapman, 2008)와 같은 다양한 단 서를 사용하였다. 연구자가 순차적으로 대상자에게 단서를 제공함 으로써, 혹은 대상자가 스스로 산출을 시도하는 방법을 통해 설단 현상이 해결되는 과정을 살펴보는 것이다.

그러나 설단 현상의 발생을 탐색한 연구는 대부분 영어권에서 보고되었으며, 설단 현상의 해결 과정을 살펴본 연구는 더욱 제한 적이다. 국내에서는 최근 몇몇 연구가 보고된 정도로 우리말을 사 용한 연구는 여전히 부족한 실정이다. Park 등(2013)은 청년집단과 노인집단을 대상으로 설단 현상의 발생 및 해결을 살펴보았고, 청 년집단보다 노인집단에서 더 많은 설단 현상이 발생하며 단어 범주 에 따라 설단 발생의 차이가 나타남을 보고하였다. 설단 현상은 인 물 및 장소와 같은 고유명사에서 더 자주 발생하였으며, 두 집단 모 두 재인보다 회상을 통한 해결을 주로 보였으나 수행의 차이는 노인 집단에서 더 크게 나타났다. 다만 위 연구에서는 추상명사나 동사. 형용사까지 포함하여 조건별 자극 수가 다소 제한적이었으며, 사전 적 정의 형태의 목표 단어에 대한 질문을 화면에 보여주고 그에 답 하는 방식을 사용함에 따라 초기에 주어지는 정보의 양이나 확실 성이 문항별로 상이할 수 있었다. Oh (2015)는 청년, 장년, 중년, 노 인집단과 경도인지장애(mild cognitive impairment, $\mathrm{MCI}$ ) 집단을 대상으로 유명인 이름대기 과제를 실시하였다. 그 결과 정상적 노 화 과정에서 연령이 증가할수록 더 많은 설단 현상이 발생하는 것 으로 나타났으나, 단서 제시에 따른 설단 현상의 해결은 오히려 감 소하는 양상을 보였다. 또한 정상 노인집단과 $\mathrm{MCI}$ 집단의 설단 현 상 발생 및 해결을 비교하였을 때, MCI집단에서 더 많은 설단 현상 이 발생하였고 설단 해결은 낮게 나타났다. 그러나 집단별 대상자 의 수가 다소 제한적이었으며, 설단 현상의 해결을 유도하기 위해 각 대상자에게 주어지는 첫 음절 또는 끝 음절 단서가 집단에 의해 구분되었기 때문에 각 단서의 영향을 직접적으로 비교하기에는 어 려움이 있었다.

이에 본 연구는 이름대기 처리와 관련된 음운 정보 산출 과정을
중심으로 정상적 노화 과정에서 어휘 특성에 따라 발생하는 설단 현상의 발생 및 해결 양상의 차이를 알아보았다. 첫째, 청년집단과 노인집단에서 설단 현상 발생의 차이가 있는지 확인하고자 단어 범 주와 빈도를 고려한 대면이름대기 과제를 사용하여 설단 현상을 유도하였다. 둘째, 청년집단과 노인집단에서 설단 현상이 발생했을 때 순차적으로 단서를 제공하여 연령 집단 간 해결 양상의 추이에 서차이가 있는지 살펴보았다.

\section{연구 방법}

\section{연구 대상}

본 연구는 서울, 경기 지역에 거주하는 청년(만 20세-29세) 20 명 과 노인(만 70세 이상) 20명을 대상으로 하였다. 두 연령 집단 모두 한국어를 모국어로 하며 과거와 현재 신경학적·정신적 질병으로 인한 진단 및 수술 경력이 없고, 검사과제 수행에 있어 시력과 청력 의 제약이 없음을 기준으로 모집하였다. 단, 노인집단의 경우 한국 판 간이정신상태검사(Korean-Mini Mental State Examination, KMMSE; Kang, Na, \& Hahn, 1997)상의 점수가 해당 연령 및 교육년 수 규준에서 $16 \%$ ile 이상이었다(Kang, 2006). 대상자는 실험 전 간 단한 인터뷰를 통해 개인 정보와 건강 상태를 보고하였으며, 최종 적으로 선정된 집단별 대상자 정보는 Table 1 과 같다. 선행 연구에 서 교육연수가 이름대기에 큰 영향을 미치는 것으로 보고됨에 따 라(Le Dorze \& Durocher, 1992; Neils et al., 1995) 본 연구에서는 두 집단의 교육수준을 통계적으로 유의한 차이가 나지 않도록 통 제하였다 $(t=1.69, p>.05)$.

\section{연구 도구}

고유명사 이름대기 도구

본 연구에서는 고유명사 범주의 특성을 알아보고자 유명인 이름 대기 과제를 사용하였다. 이를 통해 대상자들의 설단 현상을 살펴 보고자 Kim (2009), Oh (2015), Park 등(2013)의 연구를 참고하여 단어 선정 기준을 세운 뒤 수정, 보완하였다. 유명인은 시대별로 1970년대, 1980년대, 1990년대, 2000년대 이후와 범주별로 정치 및

Table 1. Descriptive information of participants

\begin{tabular}{lcc}
\hline & Young $(\mathrm{N}=20)$ & Elderly $(\mathrm{N}=20)$ \\
\hline Age $(\mathrm{yr})$ & $23.90(2.10)$ & $75.85(3.47)$ \\
Education (yr) & $14.95(1.54)$ & $13.95(2.16)$ \\
K-MMSE & - & $27.80(1.40)$ \\
\hline
\end{tabular}

Values are presented as mean (SD).

K-MMSE = Korean version of Mini-Mental Status Examination (Kang, Na, \& Hahn, 1997). 
경제계, 대중문화계(가수, 개그맨, 배우), 스포츠로 나누었다.

단어 자극을 구성하기 위해 우선 국립국어원에서 출간한 '현대 국어 사용 빈도 조사: 한국어 학습용 어휘 선정을 위한 기초조사' (Jo, 2002) 중 고유명사 빈도색인에 기초하여 빈도 순으로 나열한 후, 156 명의 유명인을 선정하였다. 다음으로 '(학계.언론계가 뽑은) 광복 50주년 한국을 바꾼 100인들'(JoongAng Ilbo Co. Ltd., 1995) 과 1989년-2014년 시사저널 한국을 움직이는 사람들, 2009년-2015 년 중앙시사매거진 포브스코리아 한국 파워 셀러브리티 TOP 10 인물을 참고하여 국내 유명인 60 명을 선정하였다. 마지막으로 객관 적 빈도에 따라 선정된 단어가 실제 사용자가 체감하는 주관적 빈 도에 적절히 부합하는지 확인하기 위해 Park (2003)의 주관적 빈도 추정법을 Likert 5점 척도(1점: 전혀 없음, 2점: 1년에 한 번, 3점: 한 달에 한 번, 4점: 일주일에 한 번, 5점: 하루에 한 번 이상)로 수정, 보 완하여 유명인 이름의 주관적 빈도 추정치를 조사하였다. 이를 통 해 전체 60 명의 유명인 중 주관적 빈도 3.0 이상에 해당하는 34 명이 선정되었고, 단어 길이는 3 음절로 통제하였다.

선정된 단어를 바탕으로 사진 자극의 타당성을 검증하였다. 연 구에 사용된 유명인 사진은 Kim (2009)과 McKenna와 Warrington (1980)의 사진 선별 기준을 참고하여 적용하였다. 사진 타 당도에 대한 사전 조사에서 대상자들이 오반응 하였거나 모른다고 보고한 비율이 높은 경우를 제외하고, 시대 분포를 고려하여 최종 적으로 총 30명의 유명인을 선정하였다(Appendix 1).

\section{일반명사 이름대기 도구}

국내에 표준화된 이름대기 검사 도구인 한국판 보스톤 이름대기 검사(Korean version-Boston Naming Test, K-BNT; Kim \& Na, 1997)가 있으나 긴 소요시간 동안 집중력을 유지하기 어렵고, 검사 항목 중 일상생활에서 사용빈도가 낮은 사물(예: 휽손, 코뚜레)이 포함되어 설단 현상을 살펴보기 위한 본 연구에 적절한 일반명사 이름대기 과제를 자체적으로 제작하였다.

일반명사 단어는 유명인 이름대기 과제와 동일한 3 음 절의 단어 로 구성하였는데, 이는 음절 길이 또한 이름대기 수행에 영향을 미 치는 변인으로 보고된 바 있으며(Le Dorze \& Durocher, 1992), 음 절 단서를 제공하기에 2 음절은 적절하지 않기 때문이었다. 단어 선 정을 위해 우선 국립국어원의 '현대 국어 사용 빈도 조사: 한국어 학습용 어휘 선정을 위한 기초조사'(Jo, 2002) 중 단어 빈도색인을 기초로 하여 빈도 순으로 나열 후, 사진으로 표현 가능한 구체명사 단어 205 개를 추출하였다. 이후 빈도 20 을 기준으로 20 이상을 고 빈도 단어, 20 미만을 저빈도 단어로 하여 각 60 개의 단어를 선정하 였다. 마지막으로 고유명사와 동일한 방법으로 주관적 빈도를 측정
하였고, 고빈도 단어지만 낮은 주관적 빈도를 나타내거나, 저빈도 단어지만 높은 주관적 빈도를 나타낸 단어는 제외시켰다(예: 나침 반, 돋보기, 뚝배기 등). 최종적으로 고빈도와 저빈도 각 18 개씩, 36 개 단어를 선정하였다.

선정된 단어를 바탕으로 유명인 이름대기 과제와 동일하게 사진 자극의 타당성을 검증하였으며, 최종적으로 총 30 개의 사물을 선 정하였다(Appendix 2).

\section{연구 절차}

본 과제의 절차는 Burke 등(1991), Oh (2015), Park 등(2013)의 연 구를 참고하여 수정, 보완하였으며, 소음이 제한된 독립된 공간에 서 개별적으로 진행되었다. 이름대기 과제 문항은 동일한 시대와 범주가 세 번 이상 연속되지 않도록 유사무선배열(quasi random order)하였고, 사진은 배경을 삭제한 동일한 크기 $(13 \mathrm{~cm} \times 15 \mathrm{~cm}$, 가로 $\times$ 세로)로 제작되어 13 인치 노트북 화면 중앙에 제시하였다. 대상자의 모든 반응은 녹음되었고, 동시에 연구자가 반응 기록지 에 기록하였다. 모든 자극은 1 회만 제시하였고, 대상자의 요청이 있 을 시 단서는 한 번 더 제공하였다.

구체적인 절차는 다음과 같다(Figure 1). 본 시행에 앞서 대상자 에게 설단 현상에 대한 정의와 실험에 대한 설명을 구두로 제시하 고, 실험 과정을 충분히 숙지할 수 있도록 3 회의 연습 문항을 실시 하였다. 화면에 목표 자극이 제시되면, 대상자는 해당 자극에 대한 자신의 상태를 다음 중 하나로 보고하였다. (1) 제시된 자극의 이름 이 누구/무엇인지 정확히 아는 경우, (2) 제시된 자극의 이름이 누 구/무엇인지 전혀 모르는 경우, (3) 제시된 자극의 이름을 분명히 안 다고 느끼지만 누구/무엇인지 생각나지 않는 경우(설단 현상)였다. 대상자가 이름을 정확히 알고 있다고 보고한 이후 이름을 산출하 도록 하였고, 모른다는 보고에는 추가로 반응을 요구하지 않으며 오반응으로 간주하였다. 대상자가 설단 현상으로 보고한 경우에 한해 다음 일련의 과정을 실시하였다.

설단 현상은 정확한 이름은 산출할 수 없더라도 그 순간에 목표 단어를 안다고 느끼는 친숙성을 전제로 한다(Brown \& McNeill, 1966). 이에 대상자가 제시된 목표 자극(유명인/사물)을 본 적이 있 거나 알고 있음을 확인하고자 설단 해결을 위한 단서 제공 전에 목 표 자극에 대한 친숙도 평정(7점 척도)을 실시하였다. 이후, "목표 자극(유명인/사물)에 대해 말해주세요.”라는 질문에 적절한 의미 정보를 말하도록 하여 자발적 설단 해결을 유도하였다. 만약 부적 절한 의미 정보를 보고했을 경우 다시 한 번 질문하였고, 재시도에 도 오반응 또는 무반응을 보인다면 해당 자극을 알지 못하는 것으 로 간주하여 해당 문항을 중지하고 다음 시행을 실시하였다. 적절 


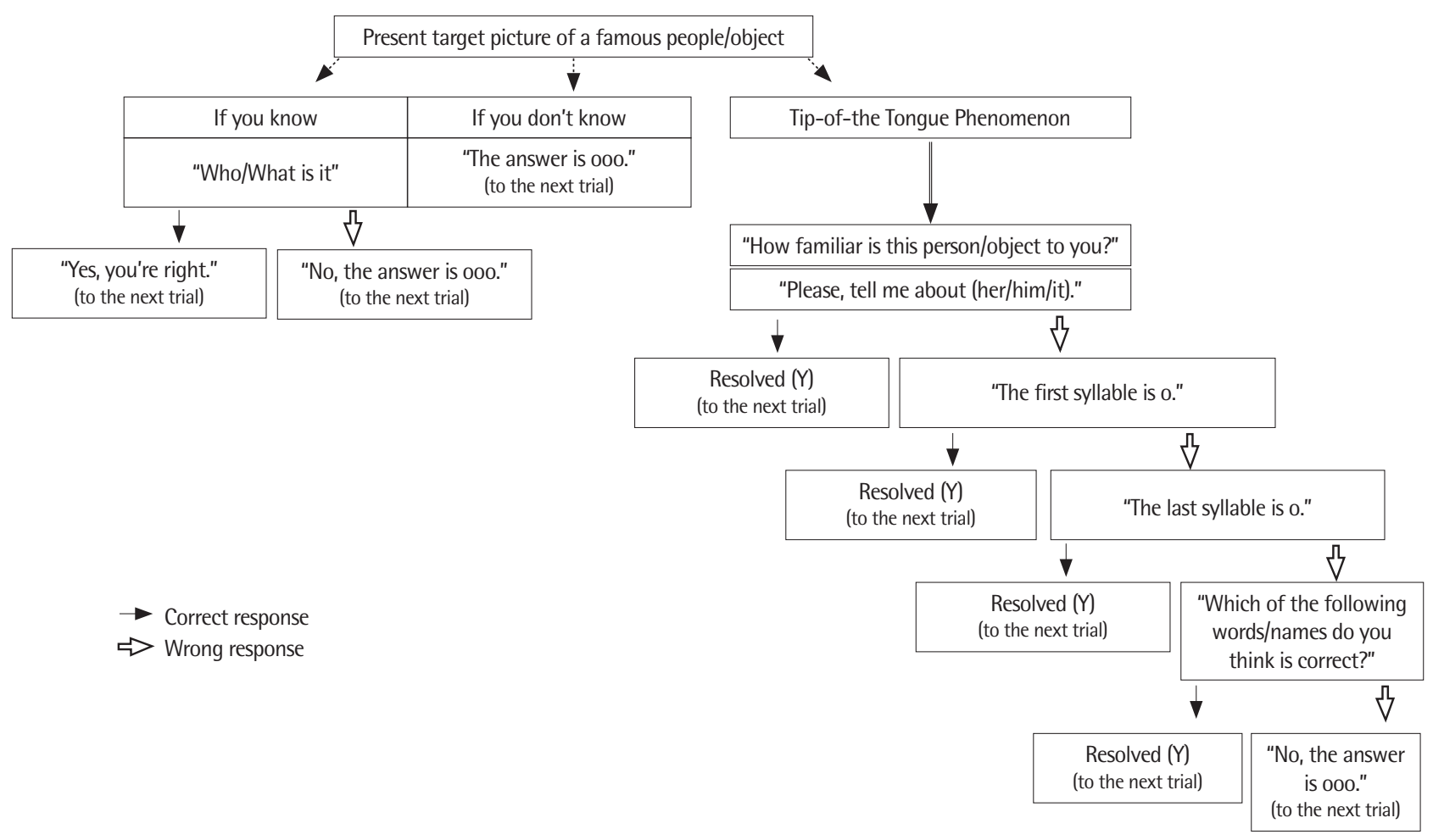

Figure 1. Procedure of the test.

한 의미 정보를 보고하였으나 자발적 설단 해결에는 실패하였을 경 우 첫음절 단서를, 그 후에도 해결되지 않으면 끝음절 단서를 순차 적으로 제공하였다. 음절 단서 제시 후에도 설단 현상이 해결되지 않거나 보고한 답이 틀렸을 경우, 최종적으로 단어 재인을 실시하 여 해당 자극을 알고 있는지 여부를 확인하였다. 재인 과제에서는 각 자극 항목 당 두 개의 보기 단어가 함께 주어졌는데 Beeson 등 (1997)의 연구를 참고하여 하나는 목표 단어와 동일한 범주 내의 다른 자극, 또 하나는 목표 단어와 전혀 무관한 범주의 자극으로 구성하였다. 대상자는 화면에 제시된 세 가지 이름 중에서 적절한 이름을 선택하여 말하였다. 설단 현상이 발생된 문항은 단계적으 로 주어지는 단서를 통해 설단 현상이 해결되는 시점에서 다음 시 행으로 진행하였다.

\section{자료 분석}

자료 분석 기준은 $\mathrm{Oh}$ (2015)의 연구를 참고하여 수정, 보완하였 다(Appendix 3). 이름대기 반응률에서 정반응률과 오반응률은 정/ 오반응 빈도를 전체 이름대기 빈도로 나눈 뒤 100 을 곱하여 산출하 였다. 만약 '알고 있음'으로 보고한 뒤 답이 틀릴 경우 오반응으로 간주하였다. 설단 현상 발생률은 설단 현상 빈도를 전체 이름대기 빈도로 나눈 뒤 100 을 곱하여 구하였다. 자발적 설단 현상 해결률 은 자발적으로 해결된 설단 현상 빈도를 전체 설단 현상 빈도로 나
눈 뒤 100 을 곱하여 산출하였다. 음절 단서 후 설단 현상 해결률은 1 차 음절 단서 후 설단 현상 해결 빈도와 2차 음절 단서 후 설단 현상 해결 빈도 각각을 이전 단계에서 해결되지 않은 설단 현상 빈도로 나눈 뒤 100 을 곱하여 산출하였다. 단어 재인을 통한 설단 현상 해 결률은 단어 재인을 통한 설단 현상 해결 빈도를 최종 단계까지 해 결되지 않은 설단 현상 빈도로 나눈 뒤 100 을 곱하여 구하였다. 만 약 단어 재인을 통해서도 설단 현상 해결에 실패한 경우는 목표 자 극이 아닌 다른 이름을 떠올린 것이므로 오반응으로 간주하였다.

수집된 자료는 SPSS ver. 20.0 통계 프로그램으로 분석하였다. 첫 째, 연령에 따른 두 집단 간 단어 범주 및 일반명사 중 단어 빈도에 따라 설단 현상 발생률의 유의한 차이가 있는지 알아보기 위해, 집 단(2)과 단어 범주(2), 집단(2)과 단어 빈도(2)를 요인으로 하는 반 복측정 이원분산분석(repeated measure two-way ANOVA)을 실시 하였다. 둘째, 설단 현상의 해결률은 설단 현상이 발생한 경우에 한 하여 분석이 가능하였기에 연령 집단 간 제공된 단서 유형에 의한 설단 해결 양상의 추이는 기술 통계 자료를 바탕으로 논의하였다.

\section{연구 결과}

본격적인 분석에 앞서 두 집단에 제시한 단어 자극에 대한 각 연 령대의 친숙성이 설단 현상의 발생 및 어휘 특성에 따른 차이에 영 
향을 미쳤을지 여부를 확인하였다. 이를 위해 연구 절차 중 설단 현 상이 발생한 시점에 대상자가 보고한 해당 자극에 대한 친숙도 평 정 결과를 분석하였다. 분석 결과, 고유명사 $(t=-1.20, p>.05)$, 일반 명사 $(t=-.96, p>.05)$, 일반명사 중 저빈도 명사 $(t=-1.52, p>.05)$ 에 서 두 집단이 보고한 친숙도 평정치에서 유의미한 차이는 나타나지 않았다. 일반명사 중 고빈도 명사의 경우는 노인집단에서만 설단 현상이 발생하였기에 분석에서 제외되었다.

청년집단과 노인집단의 단어 범주(고유/일반명사) 및 일반명사 중 단어 빈도(고/저빈도)별 정반응과 오반응 및 설단 반응에 대한 기술 통계 자료를 Tables 2와 3 에 제시하였다.

\section{설단 현상 발생률}

단어 범주별 설단 현상 발생률을 분석한 결과, 연령 집단에 따른 주효과 $\left(F_{(1,38)}=54.137, p<.01\right)$ 와 단어 범주에 따른 주효과가 유의미 하게 나타났다 $\left(F_{(1,38)}=58.859, p<.01\right)$. 즉 청년집단보다 노인집단에 서, 일반명사보다 고유명사에서 더 많은 설단 현상이 발생하였다. 또한 단어 범주와 연령 집단에 따른 상호작용 효과도 통계적으로

Table 2. Average incidence rates and frequency of correct response, wrong response and Tip-of-the-Tongue response by word category

\begin{tabular}{lccccc}
\hline & \multicolumn{2}{c}{ Proper noun } & & \multicolumn{2}{c}{ Common noun } \\
\cline { 2 - 3 } \cline { 5 - 6 } & $\%$ & Freq. & & $\%$ & Freq. \\
\hline Correct response & & & & \\
$\quad$ Young & $79.17(12.88)$ & 475 & & $92.00(5.12)$ & 552 \\
$\quad$ Elderly & $51.67(15.84)$ & 310 & & $73.33(9.43)$ & 440 \\
$\quad$ Wrong response & & & & & \\
$\quad$ Young & $8.50(4.77)$ & 52 & & $3.33(4.19)$ & 20 \\
$\quad$ Elderly & $9.83(10.46)$ & 59 & & $15.33(7.04)$ & 92 \\
Tip-of-the-Tongue response & & & & \\
$\quad$ Young & $12.17(10.16)$ & 73 & & $4.67(3.32)$ & 28 \\
$\quad$ Elderly & $38.50(15.27)$ & 231 & & $11.33(7.60)$ & 68 \\
\hline
\end{tabular}

Values are presented as mean (SD) or number.

Table 3. Average incidence rates and frequency of correct response, wrong response, and Tip-of-the-Tongue response by word frequency of common nouns

\begin{tabular}{lccccc}
\hline & \multicolumn{2}{c}{ High frequency } & & \multicolumn{2}{c}{ Low frequency } \\
\cline { 2 - 3 } \cline { 5 - 6 } & $\%$ & Freq. & & $\%$ & Freq. \\
\hline Correct response & & & & & \\
$\quad$ Young & $99.33(2.98)$ & 298 & & $85.00(10.35)$ & 255 \\
$\quad$ Elderly & $90.67(8.49)$ & 272 & & $56.00(14.25)$ & 168 \\
$\quad$ Wrong response & & & & & \\
$\quad$ Young & $.67(2.98)$ & 2 & & $5.67(6.93)$ & 17 \\
$\quad$ Elderly & $6.67(6.49)$ & 20 & & $24.00(10.01)$ & 72 \\
Tip-of-the-Tongue response & & & & \\
$\quad$ Young & $.00(.00)$ & 0 & & $9.33(6.63)$ & 28 \\
$\quad$ Elderly & $2.67(5.03)$ & 8 & & $20.00(14.18)$ & 60 \\
\hline
\end{tabular}

Values are presented as mean (SD) or number.
유의하였는데 $\left(F_{(1,38)}=18.941, p<.01\right)$, 이는 일반명사와 고유명사 간 의 수행 차이가 노인집단에서 더 두드러짐을 의미하였다(Figure 2).

일반명사 중 단어 빈도별 설단 현상 발생률 차이를 분석하였을 때, 연령 집단에 따른 주효과 $\left(F_{(1,38)}=12.929, p<.01\right)$ 와 일반명사 빈도 에 따른 주효과가 유의미하게 나타났다 $\left(F_{(1,38)}=53.527, p<.01\right)$. 다시 말해, 일반명사의 경우에도 청년집단보다 노인집단에서 더 많은 설 단 현상이 발생하였고, 단어 빈도에 따라서는 고빈도 단어보다 저빈 도 단어에서 더 많은 설단 현상이 발생하였다. 일반명사 빈도와 연령 집단에 따른 상호작용 효과도 유의미하게 나타났는데 $\left(F_{(1,38)}=4.817\right.$, $p<.05)$, 이는 고빈도 조건과 저빈도 조건의 수행 차이 역시 노인집 단에서 두드러지게 나타남을 보여주었다(Figure 3).

\section{설단 현상 해결률}

설단 현상 해결률은 설단 현상이 나타난 경우에 한하여 분석을 실시하였다. 각 연령 집단에서 발생한 전체 설단 현상 발생 빈도에 대 하여 자발적 해결 및 순차적으로 제공된 단서에 따라 해결된(1차음

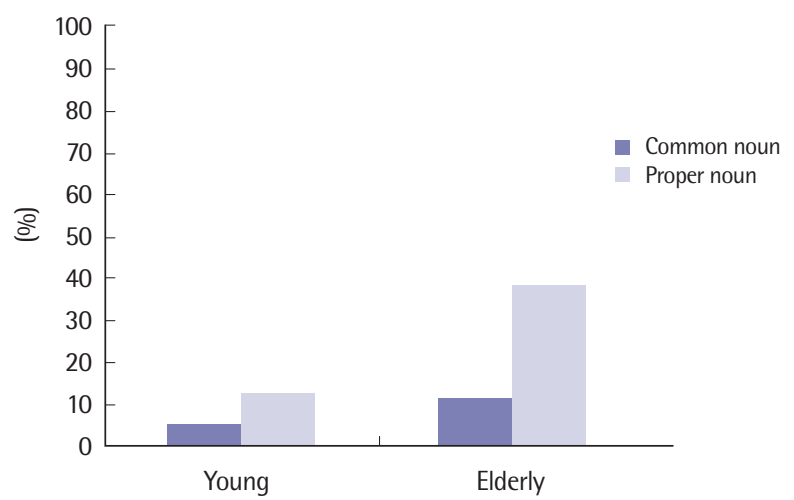

Figure 2. Differences in Tip-of-the-Tongue phenomenon incidence rates by word category.

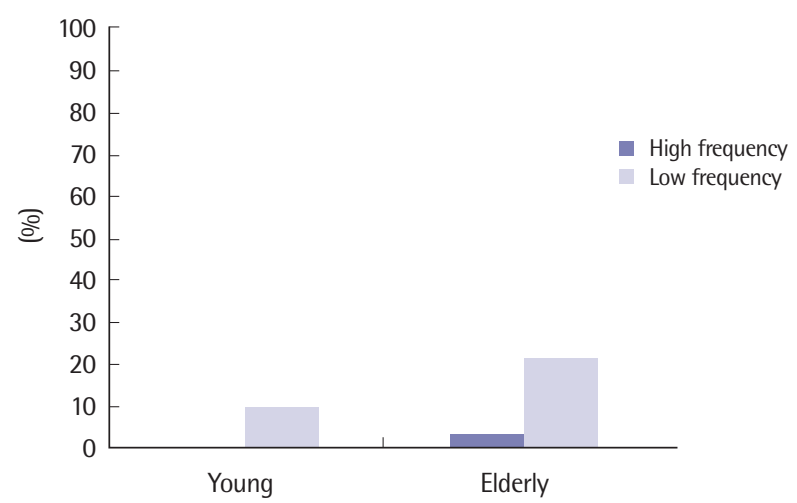

Figure 3. Differences in the Tip-of-the-Tongue phenomenon incidence rates by word frequency of common nouns. 


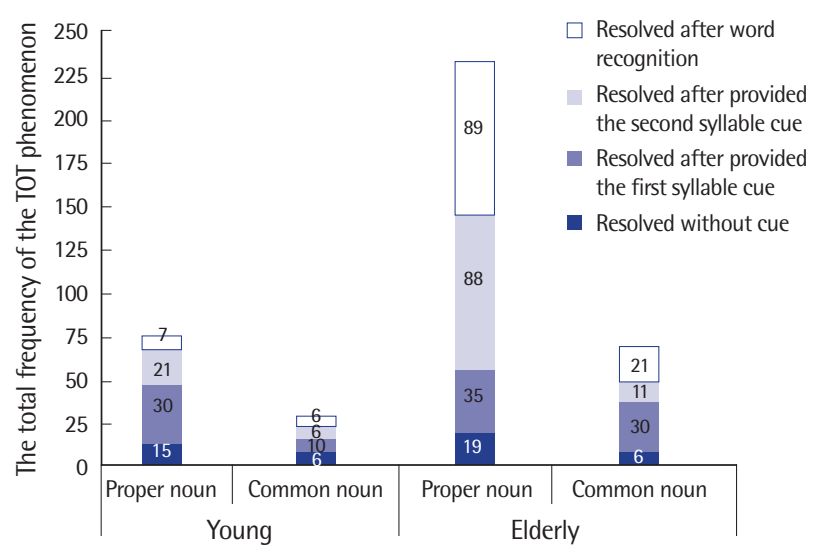

Figure 4. Aspects of resolving the Tip-of-the-Tongue phenomenon according to cues. TOT=Tip-of-the-Tongue.

절 단서 제시 후, 2 차음절 단서 제시 후, 단어 재인) 설단 현상의 해결 률과 빈도를 구한 뒤, 집단간 양상의 추이를 살펴보았다(Figure 4).

두 집단에서 발생한 설단 현상은 단서 제공에 의해 최종적으로 는 모두 해결되었으나, 해결 양상의 추이는 서로 다르게 나타났다. 고유명사에서 발생한 설단 현상의 경우 청년집단은 주로 음절 단서 제공으로 해결이 되었으며, 특히 1 차 음절 단서의 제시 후 더 많은 설단 현상의 해결이 나타났다. 반면, 노인집단은 자발적 해결과 1 차 음절 단서로 인한 해결보다, 주로 2 차 음절 단서 및 단어 재인을 통 해 설단 현상이 해결되는 양상을 보였다. 일반명사에서 발생한 설 단 현상의 경우 청년집단은 1 차 음절 단서로 설단 현상이 해결되는 빈도가 다소 높았으며, 노인집단은 주로 1 차 음절 단서와 단어 재인 을 통해 설단 현상이 해결되었다.

\section{논의 및 결론}

본 연구는 이름대기 처리 과정에서 연령과 어휘 특성에 따른 설단 현상 발생 및 해결 양상의 차이를 살펴보고자 청년과 노인을 대상으 로 단어 범주와 빈도를 고려한 이름대기 과제를 실시하여 설단 현상 을 유도한 뒤그 결과를 비교하였다. 주요 연구 결과는 다음과 같다.

첫째, 단어 범주와 빈도를 고려한 이름대기 과제에서 청년에 비 해 노인이 더 많은 설단 현상을 보고하였다. 이는 청년보다 노인이 더 많은 설단 현상을 경험한다는 선행 연구들(Burke et al., 1991;

Evrard, 2002; James, 2006; James \& Burke, 2000; Rastle \& Burke, 1996)의 결과와 일치하는 것이었으며, 전달 손실 가설과 같은 맥락 에서 설명될 수 있다(Burke, MacKay, \& James, 2000; Burke et al., 1991; Burke \& Shafto, 2004; Dahlgren, 1998). 즉, 설단 현상은 음운 마디 간의 불충분한 정보 전달 또는 연결의 약화로 인해 발생할 수
있으며, 연령 증가에 따른 마디 연결의 약화로 인해 전달 결함이 증 가하기 때문에 청년보다 노인의 경우 더 많은 설단 현상을 경험하 게 된다. 더불어 노화로 인해 의미적 표상의 활성화가 어휘 산출에 요구되는 수준을 충족하지 못하게 됨에 따라 이름의 인출에 어려 움을 겪게 되는 것일 수 있다(Hodgson \& Ellis, 1998).

둘째, 청년집단과 노인집단의 단어 범주에 따른 설단 발생의 차이 를 분석한 결과, 청년집단과 노인집단 모두 일반명사보다 고유명사 에서 더 많은 설단 현상이 발생하였다. 선행 연구들에서도 이와 유 사한 결과들이 보고되었는데(Burke et al., 1991; Evrard, 2002; Rastle \& Burke, 1996), 이 또한 전달 손실 가설을 통해 해석해볼 수 있 다. Verstichel, Cohen과 Crochet (1996)의 연구에 따르면 일반명사 의 의미 정보는 하나의 일반명사에 많은 지시 대상을 연결한다. 일반 명사의 경우 하나의 단어에서 여러 의미 정보의 활성화에 의존하며, 이러한 활성화는 일반명사의 이해를 도와준다고 알려져 있다. 반면, 고유명사는 하나의 이름에 유일한 대상을 연결한다. 즉, 일반명사의 경우 의미 마디의 연결이 약화되어 불충분한 점화가 일어나더라도 여러 의미 마디와의 연결을 통해 점화가 가능하며 음운 마디에 정보 를 전달할 수 있게 된다. 반면, 고유명사는 의미 마디의 연결이 약화 되어 불충분한 점화가 발생한다면 대체할 수 있는 다른 의미 마디와 의 연결이 없기 때문에 전달 손실을 겪게 된다. 이로 인해 일반명사 보다 고유명사에서 더 많은 설단 현상이 발생하게 된다는 것이다.

또한 일반명사 중 단어 빈도에 따른 설단 현상 발생의 차이를 분 석한 결과, 두 집단 모두 고빈도 단어보다 저빈도 단어에서 더 많은 설단 현상이 나타났다. 이는 저빈도 단어에서 더 많은 설단 현상이 발생함을 보고한 선행 연구들(Burke \& Laver, 1990; Harley \& Bown, 1998)의 결과와 일치한다. 일반적인 단어 빈도 효과(word frequency effect)에 따르면 고빈도 단어에 비해 저빈도 단어를 인식 하거나 처리하는 데 어려움이 있다(Taft, 1979). 이러한 요인의 작용 으로 사용 빈도가 높은 고빈도 단어는 음운 마디의 강한 연결을 토 대로 인출되는 반면, 사용 빈도가 낮은 저빈도 단어는 음운 마디 연 결이 약하기 때문에 고빈도 단어보다 설단 현상이 발생할 가능성 이 상대적으로 높다(Burke et al., 1991; Burke \& Shafto, 2004; Schwartz, 1999).

흥미로운 점은 위에서 살펴본 어휘 특성에 따른 차이가 노인집 단에서 더욱 두드러지게 나타났다는 것이다. 단어의 범주나 빈도와 같은 어휘의 특성에 따라 다르게 구성된 의미 체계 내의 마디 연결 구조가 음운 정보 전달 과정에 영향을 미치는 것은 두 연령 집단에 서 유사할 수 있으나, 노화에 따라마디 연결 강도나 활성화수준측 면에서의 기능이 저하되기 때문에 결과적으로 청년집단보다 노인 집단에서 더 많은 설단 현상이 관찰되는 것으로 해석된다(Burke et 
Ye Ni Lee, et al. • Tip-of-the-Tongue Phenomenon between Youth and Elderly

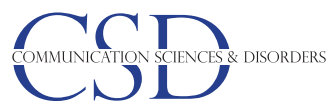

al., 1991; Burke \& Shafto, 2004).

셋째, 청년집단과 노인집단의 단어 범주 및 일반명사 중 빈도에 따라 발생한 설단 현상은 단서 제공에 의해 모두 해결되었으나, 그 추이는 서로 다르게 나타났다. 이는 정상적 노화에 따라 단서 제공 에 의한 설단 현상 해결률의 감소가 나타난 Oh (2015)의 연구와는 상반된 결과이다. 이러한 차이는 설단 현상이 발생했을 때, 해결을 위한 단서 제공 방법의 차이로 인한 것이라 판단된다. 본 연구에서 는 고유명사에서 발생한 설단 현상의 경우 청년집단은 주로 1 차 음 절 단서에 의해 해결되었고, 노인집단은 2 차 음절 단서와 단어 재인 을 통한 해결이 더 많이 나타났다. 또한 일반명사에서 발생한 설단 현상의 경우 청년집단은 주로 1 차 음절 단서에 의해 해결되었고, 노 인집단은 주로 1 차 음절 단서와 단어 재인을 통한 해결이 나타났다. 이 같은 결과는 설단 현상의 해결을 위해 청년에 비해 노인에게 더 많은 인출 단서(retrieval cue)가 필요함을 시사한다. James와 Burke (2000)는 전달 결함으로 인해 발생한 설단 현상의 해결을 위해서 는, 음운적으로 관련된 단서들을 제시하여 약화된 음운적 연결을 강화시키는 것이 필요함을 언급한 바 있다. 특히 본 연구에서 노인 집단은 고유명사에서 발생한 설단 현상의 해결에 더 많은 단서가 필요했는데, 이는 일반적으로 고유명사가 일반명사보다 인출 과정 이 복잡하며 연령의 증가에 따라 고유명사 산출에 더 어려움을 겪 는다는 결과를 지지한다고 볼 수 있다. 이처럼 비록 노화에 의해 설 단 현상이 발생하더라도 충분한 단서가 제공되면 설단 현상이 해결 될 수 있으며, 특히 설단 현상을 경험하는 동안에 제공되는 음운 단 서(phonological cue)의 경우 설단 현상의 해결은 물론 목표 단어의 활성화를 촉진시킬 수 있다고 보고한 연구 결과들은(Burke et al., 1991; Rastle \& Burke, 1996; White \& Abrams, 2002) 임상적으로 시사하는 바가 크다고 하겠다.

본 연구는 고유명사 인물 선정 시 연령 간격이 큰 두 집단이 고루 인지할 수 있는 인물을 선정하기 위해 객관적 자료를 참고하고 타 당성을 높이고자 노력하였으나, 대상자의 개인적 경험에 따른 차이 가 과제 수행에 영향을 미쳤을 수 있다. 또한 일반명사 조건의 경우 항목 수가 제한적이었으므로 연구 결과의 해석에 주의를 요한다. 본 연구에서 확인된 청년집단과 노인집단 간 어휘 특성에 따른 설 단 현상 발생 및 해결 양상의 차이를 토대로 후속 연구에서는 연령 별 추이를 보다 구체적으로 비교하고, 나아가 일반적 노화와 병리 적 노화의 차이를 살펴보는 시도가 이어져야 할 것이다.

\section{REFERECES}

Abrams, L., White, K. K., \& Eitel, S. L. (2003). Isolating phonological compo- nents that increase tip-of-the-tongue resolution. Memory \& Cognition, 31, 1153-1162.

Beeson, P. M., Holland, A. L., \& Murray, L. L. (1997). Naming famous people: an examination of tip-of-the-tongue phenomena in aphasia and Alzheimer's disease. Aphasiology, 11, 323-336.

Brown, A. S., \& Nix, L. A. (1996). Age-related changes in the tip-of-thetongue experience. American Journal of Psychology, 109, 79-91.

Brown, R., \& McNeill, D. (1966). The "tip of the tongue" phenomenon. Journal of Verbal Learning and Verbal Behavior, 5, 325-337.

Bruce, V., \& Young, A. (1986). Understanding face recognition. British Journal of Psychology, 77, 305-327.

Burke, D. M., \& Laver, G. D. (1990). Aging and word retrieval: selective age deficits in language. In E. A. Lovelace (Ed.), Aging and cognition: mental processes, self-awareness and interventions (pp. 281-300). Amsterdam: North-Holland.

Burke, D. M., \& Shafto, M. A. (2004). Aging and language production. Current Directions in Psychological Science, 13, 21-24.

Burke, D. M., \& Shafto, M. A. (2008). Language and aging. In F. I. M. Craik $\&$ T. A. Salthouse (Eds.), The handbook of aging and cognition (3rd ed., pp. 373-443). New York, NY: Psychology Press.

Burke, D. M., MacKay, D. G., \& James, L. E. (2000). Theoretical approaches to language and aging. In T. J Perfect\& E. A. Maylor (Eds.), Models of cognitive aging (pp. 204-237). Oxford: Oxford University Press.

Burke, D. M., MacKay, D. G., Worthley, J. S., \& Wade, E. (1991). On the tip of the tongue: what causes word finding failures in young and older adults? Journal of Memory and Language, 30, 542-579.

Cohen, G., \& Faulkner, D. (1986). Memory for proper names: age differences in retrieval. British Journal of Developmental Psychology, 4, 187-197.

Connor, L. T., Spiro, A., Obler, L. K., \& Albert, M. L. (2004). Change in object naming ability during adulthood. Journals of Gerontology Series B: Psychological Sciences and Social Sciences, 59, P203-P209.

Dahlgren, D. J. (1998). Impact of knowledge and age on tip-of-the-tongue rates. Experimental Aging Research, 24, 139-153.

Ecke, P., \& Garrett, M. F. (1998). Lexical retrieval stages of momentarily inaccessible foreign language words1. Iha do Desterro: A Journal of English Language, Literatures in English and Cultural Studies, (35), 157-183.

Ellis, A. W., \& Young, A. W. (1989). Human cognitive neuropsychology. Hove: Lawrence Erlbaum Associates.

Evrard, M. (2002). Ageing and lexical access to common and proper names in picture naming. Brain and Language, 81, 174-179. 
Farmer, A. (1990). Performance of normal males on the Boston Naming Test and the Word Test. Aphasiology, 4, 293-296.

Goulet, P., Ska, B., \& Kahn, H. J. (1994). Is there a decline in picture naming with advancing age? Journal of Speech, Language, and Hearing Research, 37, 629-644.

Hanley, J. R., \& Chapman, E. (2008). Partial knowledge in a tip-of-the-tongue state about two-and three-word proper names. Psychonomic Bulletin \& Review, 15, 156-160.

Harley, T. A., \& Bown, H. E. (1998). What causes a tip-of-the-tongue state? Evidence for lexical neighbourhood effects in speech production. British Journal of Psychology, 89, 151-174.

Heine, M. K., Ober, B. A., \& Shenaut, G. K. (1999). Naturally occurring and experimentally induced tip-of-the-tongue experiences in three adult age groups. Psychology and Aging, 14, 445-457.

Hodgson, C., \& Ellis, A. W. (1998). Last in, first to go: age of acquisition and naming in the elderly. Brain and Language, 64, 146-163.

James, L. E. (2006). Specific effects of aging on proper name retrieval: now you see them, now you don't. Journals of Gerontology Series B: Psychological Sciences and Social Sciences, 61, P180-P183.

James, L. E., \& Burke, D. M. (2000). Phonological priming effects on word retrieval and tip-of-the-tongue experiences in young and older adults. Journal of Experimental Psychology: Learning, Memory, and Cognition, 26, 1378-1391.

Jo, N. H. (2002). Research on frequency of using modern Korean: basic survey for vocabulary selection for Korean language study. Seoul: National Institute of Korean Language.

Jones, G. V. (1989). Back to Woodworth: role of interlopers in the tip-of-thetongue phenomenon. Memory \& Cognition, 17, 69-76.

JoongAng Ilbo Co. Ltd. (1995). 100 People who changed Korea selected by academia and media for the 50th anniversary of independence. Seoul: Author. Juncos-Rabadán, O., Facal, D., Lojo-Seoane, C., \& Pereiro, A. X. (2013). Tipof-the-tongue for proper names in non-amnestic mild cognitive impairment. Journal of Neurolinguistics, 26, 409-420.

Kang, Y. (2006). A normative study of the Korean-Mini Mental State Examination (K-MMSE) in the elderly. Korean Journal of Psychology: General, 25, 1-12.

Kang, Y., Na, D. L., \& Hahn, S. H. (1997). A validity study on the Korean Mini-Mental State Examination (K-MMSE) in dementia patients. Journal of the Korean Neurological Association, 15, 300-308.

Kim, H. H., \& Na, D. L. (1997). Korean-Boston Naming Test (K-BNT). Seoul:
Hakjisa.

Kim, M. J. (2009). Famous people naming and identification ability depending on severity in Alzheimer's disease (Master's thesis). Ewha Womans University, Seoul, Korea.

Le Dorze, G., \& Durocher, J. (1992). The effects of age, educational level, and stimulus length on naming in normal subjects. Journal of Speech-Language Pathology and Audiology, 16, 21-29.

Maylor, E. A. (1990). Age, blocking and the tip of the tongue state. British Journal of Psychology, 81, 123-134.

McKenna, P., \& Warrington, E. K. (1980). Testing for nominal dysphasia. Journal of Neurology, Neurosurgery \& Psychiatry, 43, 781-788.

Neils, J., Baris, J. M., Carter, C., Dell'aira, A. L., Nordloh, S. J., Weiler, E., \& Weisiger, B. (1995). Effects of age, education, and living environment on Boston Naming Test performance. Journal of Speech, Language, and Hearing Research, 38, 1143-1149.

Nicholas, M., Barth, C., Obler, L. K., Au, R., \& Albert, M. L. (1997). Naming in normal aging and dementia of the Alzheimer's type. In H. Goodglass \& A. Wingfield (Eds.), Anomia: neuroanatomical and cognitive correlates (pp. 166-188). San Diego, CA: Academic Press.

Oh, S. A. (2015). The effects of aging and mild cognitive impairment on tip-ofthe-tongue phenomenon in times of people naming task (Master's thesis). Daegu University, Gyeongsan, Korea

Park, J., Lee, K. E., \& Lee, H. W. (2013). The effects of aging on retrieval of phonological knowledge in Korean: the tip-of-the-tongue phenomenon in young and older adults. Korean Journal of Cognitive Science, 24, 111-132.

Park, S. (2015). Cognitive aging and language: a psycholinguistic approach. Studies in Modern Grammar, 83, 25-39.

Park, T. (2003). Subjective frequency estimates of Korean words and frequency effect on word recognition. Korean Journal of Experimental Psychology, 15, 349-366.

Rastle, K. G., \& Burke, D. M. (1996). Priming the tip of the tongue: effects of prior processing on word retrieval in young and older adults. Journal of Memory and Language, 35, 586-605.

Robson, J., Marshall, J., Pring, T., Montagu, A., \& Chiat, S. (2004). Processing proper nouns in aphasia: evidence from assessment and therapy. Aphasiology, 18, 917-935.

Schwartz, B. L. (1999). Sparkling at the end of the tongue: the etiology of tipof-the-tongue phenomenology. Psychonomic Bulletin \& Review, 6, 379393.

Taft, M. (1979). Recognition of affixed words and the word frequency effect. 
Ye Ni Lee, et al. • Tip-of-the-Tongue Phenomenon between Youth and Elderly

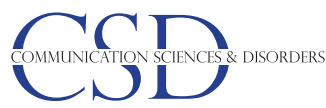

Memory \& Cognition, 7, 263-272.

Valentine, T., Brennen, T., \& Brédart, S. (1995). Cognitive psychology of proper names. London: Routledge.

Verstichel, P., Cohen, L., \& Crochet, G. (1996). Associated production and comprehension deficits for people's names following left temporal lesion.
Neurocase, 2, 221-234.

White, K. K., \& Abrams, L. (2002). Does priming specific syllables during tip-of-the-tongue states facilitate word retrieval in older adults? Psychology and Aging, 17, 226-235. 
Appendix 1. 유명인 이름대기 목록

강호동, 김건모, 김대중, 김연아, 김영삼, 김정일, 나훈아, 노무현, 노태우, 류현진, 문재인, 박근혜, 박정희, 박지성, 박태환, 박찬호, 유재석, 이건희, 이경규, 이미자, 이명박, 이병헌, 이승기, 이주일, 전두환, 정주영, 조용필, 차범근, 최불암, 최진실

1) 시대별 분류

\begin{tabular}{ll}
\hline 시대 & \multicolumn{1}{c}{ 이름 } \\
\hline 1970년대 & 차범근, 박정희, 정주영, 이미자, 나훈아 \\
1980년대 & 전두환, 노태우, 이건희, 이주일, 조용필, 최불암 \\
1990년대 & 박찬호, 김대중, 김정일, 김영삼, 이경규, 김건모, 최진실 \\
2000년대 & 김연아, 박지성, 류현진, 박태환, 문재인, 노무현, 박근혜, \\
& 이명박, 유재석, 강호동, 이병헌, 이승기 \\
\hline
\end{tabular}

2) 범주별 분류

\begin{tabular}{ll}
\hline 범주 & \multicolumn{1}{c}{ 이름 } \\
\hline 정치, 경제 & 문재인, 노무현, 박근혜, 이명박, 김대중, 김정일, 김영삼, \\
& 전두환, 노태우, 이건희, 정주영, 박정희 \\
대중문화 & 유재석, 강호동, 이병헌, 이승기, 이경규, 김건모, 최진실, \\
& 이주일, 조용필, 최불암, 이미자, 나훈아 \\
스포츠 & 김연아, 박지성, 류현진, 박찬호, 차범근, 박태환 \\
\hline
\end{tabular}

Appendix 2. 일반명사 이름대기 목록

\begin{tabular}{|c|l|}
\hline 고빈도 & $\begin{array}{l}\text { 계산기, 넥타이, 마이크, 손수건, 신호등, 오렌지, 오징어, 옥수수, } \\
\text { 자전거, 카메라, 컴퓨터, 콩나물, 토마토, 피아노, 햄버거 }\end{array}$ \\
\hline 저빈도 & $\begin{array}{l}\text { 거품기, 나막신, 돗자리, 두레박, 무전기, 분무기, 샌드백, 선인장, } \\
\text { 소화기, 안전모, 앵무새, 온도계, 자물쇠, 족두리, 줄넘기 }\end{array}$ \\
\hline
\end{tabular}

Appendix 3. 자료 분석 항목

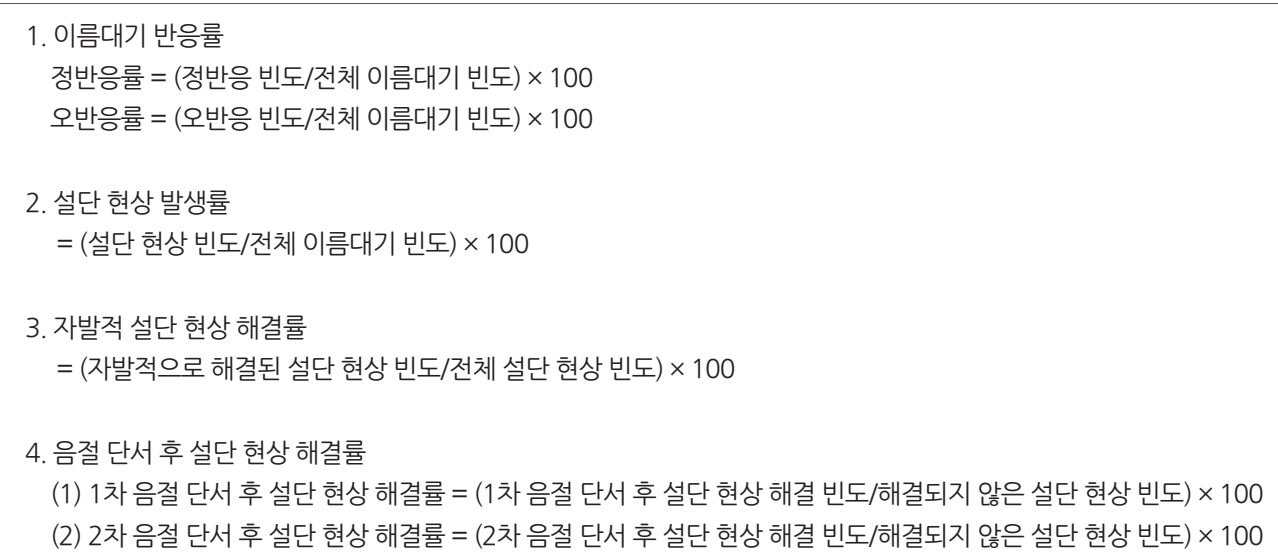

5. 단어 재인을 통한 설단 현상 해결률 $=($ 단어 재인을 통한 설단 현상 해결 빈도 $/$ 해결되지 않은 설단 현상 빈도 $) \times 100$ 


\section{국문초록}

\section{청년과 노인집단에서 어휘 특성에 따른 설단 현상 발생 및 해결 양상의 차이 \\ 이예니 ${ }^{1}$ 최소영 \\ '단국대학교 특수교육대학원 특수교육학과, ${ }^{2}$ 단국대학교 특수교육대학원}

배경 및 목적: 본 연구에서는 이름대기 처리 과정 중 음운 정보 산출 과정의 손상에 초점을 맞춰, 정상적 노화에 따른 설단 현상 발생 및 해결 양상의 차이를 알아보고자 하였다. 방법: 청년(만 20세-29세) 20 명과 노인(만 70세 이상) 20명을 대상으로 단어 범주와 빈도를 고려한 이름대기 과제를 통해 설단 현상을 유도하였다. 결과: 청년집단보다 노인집단에서 더 많은 설단 현상이 관찰되었다. 두 연령 집 단 모두 일반명사보다 고유명사에서, 일반명사 중 고빈도 단어보다 저빈도 단어에서 더 많은 설단 현상이 발생하였으나, 이러한 수행의 차이는 노인집단에서 더 크게 나타났다. 두 집단의 단어 범주 및 일반명사 중 빈도에 따라 발생한 설단 현상은 순차적인 단서 제공에 의 해 모두 해결되었으나, 청년집단보다 노인집단에서 설단 해결을 위한 더 많은 인출 단서가 필요하였다. 논의 및 결론: 본 연구는 노화가 음운 정보 산출 과정에 미치는 영향을 설단 현상의 발생과 해결 양상을 통해 경험적으로 확인하였으며, 그와 관련된 어휘 특성에 관한 기초 자료를 제공하였다는 데 의의가 있다.

핵심어: 설단 현상, 노화, 이름대기, 단어 범주, 단어 빈도

본 연구는 2015년 한국언어청각임상학회 이승환장학금 지원에 의한 연구임.

\section{참고문헌}

강연욱(2006). K-MMSE (Korean-Mini Mental State Examination)의 노인 규준 연구. 한국심리학회지: 일반, 25, 1-12. 강연욱, 나덕렬, 한승혜(1997). 치매환자들을 대상으로 한 K-MMSE 타당도연구. 대한신경과학회지, 15, 300-308. 김미정(2009). 알쯔하이머 치매환자의 중증도에 따른 유명인 이름대기 및 식별 능력 연구. 이화여자대학교대학원 석사학위 논문. 김향희, 나덕렬(1997). 한국판 보스톤 이름대기 검사(K-BNT). 서울: 학지사. 박순혁(2015). 인지노화와 언어: 심리언어학 접근 현대문법연구, 83, 25-39. 박지윤, 이고은, 이혜원(2013). 한국어 음운 정보 산출에서 노화의 영향: 청년과 노인의 설단현상. 인지과학, 24, 111-132. 박태진(2003). 한국어 단어의 주관적 빈도 추정치 및 단어 재인에 미치는 빈도 효과. 한국심리학회지: 실험, 15, 349-366. 오상아(2015). 노화와 경도인지장애가 사람이름 인출시 설단현상에 미치는 영향. 대구대학교대학원 석사학위 논문. 조남호(2002). 현대 국어 사용 빈도 조사: 한국어학습용 어휘 선정을 위한 기초조사. 서울: 국립국어연구원. 중앙일보사(1995). (학계·언론계가 뽑은)광복 50주년 한국을 바꾼 100인. 서울: 중앙일보사. 